\title{
ABOUT THE FIRST ESTONIAN TEXTBOOK AND MANUAL OF FORENSIC MEDICINE
}

23 July 2001 marked the centenary of the birth of Gerhard-Gottfried Rooks, a long-time faculty member of the University of Tartu, professor of forensic medicine, later an anatomist, and science historian. He is remembered first and foremost for his textbook and manual of forensic medicine, published in 1938, which was the first Estonian-language university textbook and manual in this field of science. In earlier times such textbooks had been published in Tartu (Dorpat, Jurjev) only in German and Russian because these were the languages of tuition at this Russian state university.

The opening of the University of Tartu in the newly independent Republic of Estonia was preceded by considerable discussion concerning the essence of the university and its language of tuition. The preparatory committee for the reopening of the university decided that the Estonian national university must be only an Estonian-language university. This decision put the Estonian nation among those nations who can contribute to the development of academic culture in their native language. The first important task of the Estonian-language university was to develop Estonian scientific terminology. At first Estonian specialists were unavailable for many fields; medicine was not an exception in this respect. By the inauguration of the University of Tartu on 1 December 1919 the medical faculty had six professors and two Privatdozents. Three faculty members taught in Estonian, three in German, and two in Russian. After five years half of the 24 members of the medical faculty were Estonian; there were ten Germans and two German Jews, and half of the courses were taught in German. In 1930 most lectures were already held in Estonian. After the Baltic Germans resettled in Germany, the faculty staff became fully Estonian by 1939. Despite some difficulties the first mother-tongue textbooks for medical students were published soon after the Estonian-language university was opened. At the end of 1919 Aadu Luus (1878-1967), the future professor of paediatrics, published "How to care for children and treat them", in 1924 Aleksander Paldrok (1871-1944), professor of dermatology and venereal diseases, published "Venereal Diseases", and next year Karl Schlossmann (1885-1969), professor of bacteriology, published "General microbiology together with microbiological techniques". The publishing of Estonian-language textbooks accelerat- 
ed after the University Council recommended to develop scientific thinking in students by applying such teaching methods that would stimulate self-study, that is, practical tasks, colloquia, and seminars because they required the existence of textbooks. Thus, in 1938 Nikolai Veiderpass (1887-1971), professor of applied pharmacy, published "Recipes in Pharmacy", Ernst Blessig (1859-1940), professor of ophthalmology, published "Ocular Diseases", and Gerhard-Gottfried Rooks, professor of forensic medicine, published a textbook and manual "Forensic Medicine". The publication of three previously mentioned books became possible thanks to the Academic Cooperative publishing house, founded in 1929. One of the main tasks of this publishing house was to publish Estonian-language textbooks [1].

Next we will take a look at the scientific and teaching activities of Professor Rooks-the author of the textbook and manual of forensic medicine. GerhardGottfried Rooks was born in the town of Cēsis in Latvia on 23 July 1901 as a son of a master builder. He received his primary education in Jōhvi and continued his education at the Boys' Grammar School in Narva. As a schoolboy he joined the Defence League as a volunteer in November 1918; during the following winter months he participated in the Estonian War of Independence. He continued his studies at the Tallinn Evening Secondary School and finished it in 1920, at the same time earning his livelihood as a postal official. In autumn of the same year he was admitted to the medical faculty of the University of Tartu. He graduated from the university cum laude as a doctor in December 1925. He was a member of the academic fraternity Rotalia.

Already during his student years Rooks was known for his thirst for knowledge, his aspiration to learn more and to extend his horizons. He went on hiking trips to many places in Estonia and participated in student field trips to West European universities. During his student years he worked for a short time at the university's clinic of internal medicine, later at the Institute of Forensic Medicine, where he started his enthusiastic research activities in this field [2]. He submitted his first research results as an entry in the essay competition "Suicides on the basis of autopsy reports at the Institute of Forensic Medicine at the University of Tartu" organized by the medical faculty in 1924. Rooks' essay won the first prize [3]. In the same year medical student Aleksandra Ibrus won the second prize at the same essay competition [4]. The author of the latter essay became a professor of forensic medicine in twenty years [5]. The next research paper by medical student Gerhard Rooks was published in the May 1925 issue of the journal "Estonian Physician", which discussed the measurements of newborn children and their afterbirth [6].

After graduation Rooks continued to work in the field of forensic medicine under the supervision of Siegfried Ferdinand Talvik (1878-1929), since 1 January 1926 as a temporary ancillary worker of the Institute of Forensic Medicine, since 1 March 1927 as a junior teaching assistant. In June that year he visited Prof. M. Nippe at 
the Institute of Forensic and Social Medicine of the University of Königsberg, acquainting himself with the new information on blood types. After passing the exams for the level of doctor of medicine Rooks became a senior teaching assistant since 1 June 1928. During the summer he visited Paris and Lyon as a fellow of the French Institute. He also visited institutes of forensic medicine in Modena, Innsbruck, Vienna, Budapest, Prague, Cracow, Warsaw, and Riga. He then left the university on 1 February 1929 and became an acting forensic and police physician of Tartu. On 5 March 1929 he was nominated permanently for this position, at the same time remaining a voluntary teaching assistant of the Institute of Forensic Medicine. In 1930 the State Gazetteer published "Guidelines for forensic autopsies" that he had compiled at the proposal of the Office Health and Social Work.

On 7 May 1932 Rooks defended a doctoral dissertation "About the distribution of blood types and prospects of establishing paternity by blood types in Estonia". In the same year he attended a course for rural and urban doctors at the university and qualified accordingly. After delivering his venia legendi lecture "About the classification of non-lethal injuries according to Estonian legislation" on 17 October 1932 before the academic council of the medical faculty, the University Council confirmed him as Privatdozent on October 25. In the spring semester of the following year he began to teach forensic medicine to law students. The State Elder's resolution of 11 May 1934 confirmed G. Rooks MD as docent of forensic medicine and director of the Institute of Forensic Medicine of the University of Tartu for three years. In that year he visited Berlin, Jena and Munich. On 11 May 1937 the medical faculty elected G. Rooks MD as an extraordinary professor in forensic medicine. In the same year he was elected as board member of the Association of Estonian Doctors and corresponding member of the Academic Association of Finnish Doctors. In September 1938 he made a report on Estonian accident legislation at the First International Congress of Forensic and Social Medicine in Bonn; after that he met his colleagues in Berlin, Königsberg and Kaunas.

By a resolution of the Government of Estonia of 2 November 1939 Prof. G. Rooks was sent as a forensic expert to Leningrad in order to attend the autopsies of three Soviet soldiers who had perished in Saaremaa. By resolution No. 210 of the minister of education of 19 December 1939 Prof. G. Rooks was confirmed to fulfil the responsibilities of the medical faculty of the University of Tartu from 1 January 1940 to 1 January 1942. 21 June 1940 brought along drastic changes also in the organization of Estonian higher education; the University of Tartu became Tartu State University. Resolution No. 210 of the People's Commissar for Education of the Estonian SSR of 26 December 1940 confirmed G. Rooks MD as the head and professor of the Department of Forensic Medicine, who also remained dean of the medical faculty. In connection with the necessity to reorganize teaching and research he visited the medical institutes of Leningrad and Moscow from 27 April to 11 May 1941 together with other representatives of the medical faculty (Prof. V. Hiie, Prof. A. Tomingas, Prof. V. Vadi, Prof. A. Valdes). The first year of the 
Soviet university witnessed extensive restructuring. Much was accomplished, much work was planned for the following years, but this peaceful development was interrupted by the war that broke out in summer. Soon the war reached Tartu too.

When in 1942 the faculties of medicine, veterinary science, and agriculture resumed their work, the university law of the Republic of Estonia was applied. Previous structures and syllabuses were used. The German occupying authorities kept Prof. Rooks as the head of the Institute of Forensic Medicine but removed him from the position of the dean. Despite this, at the beginning of April 1944 he received an invitation from the German ministry of education to deliver guest lectures there. In the turmoil of the war summer Prof. Rooks was on vacation during the first two weeks of August and at the end of the same month he left for Germany with his family [2]. In October 1944 Rooks took up the position of a research fellow at the Institute of Forensic Medicine at Halle University; later he became the deputy director of the latter institute. From 1 January 1947 until his departure for Estonia Rooks was the full professor and head of the department of forensic medicine. In addition to the university, Prof. Rooks worked as a consultant of pathology and forensic medicine at the Soviet military hospital in Halle, often acting as an expert of forensic medicine.

After returning to Estonia on 20 December 1947 G. Rooks had to work as a senior lecturer of the Department of Anatomy at Tartu State University [7] because since 16 January 1945 Prof. Aleksandra Raatma (née Ibrus, 1901-1967) had been the Head of the Department of Forensic Medicine, and all the positions of this department were full [5]. On 1 September 1954 Rooks continued to work as an acting docent of the Department of Anatomy. Since 1 September 1955 he was the acting docent and the head of the department, since 14 June 1958 a docent and the head of the department, and since 1 September 1963 an acting professor and the head of the department [7]. During his work at the department Rooks was an active researcher; he made reports at various conferences of anatomists in Leningrad, Moscow, Kiev, Kaunas, etc. He also participated in the activities of the Academic Society of Anatomists, Histologists, and Embryologists of the Estonian SSR and acted as a chairman of the society in 1961-1963 [8].

During his work at the Department of Anatomy the leadership of the medical faculty and Tartu State University applied repeatedly but to no avail to the Higher Appraisal Committee of the Ministry of Higher Education of the Soviet Union in order to have his doctoral dissertation recognized and his professorship reinstated. On 1 July 1964 he retired and moved to Tallinn [7]. After a few months, on 1 September 1964, Docent Rooks took up the position of physician, and a senior lecturer with an academic degree, and became the head of the special preparatory course (preparatory course in medicine) at the Department of Natural Sciences at the Tallinn Pedagogical Institute named after E. Vilde. On 14 October 1965 he was elected as a docent of the same department; on 1 July 1968 he retired from this position for health reasons [9]. 
G. Rooks published over sixty papers in Estonian, German, Russian, and French that were published both in Estonia and abroad. Most of them deal with the theory and practice of forensic medicine; they were quoted in a number of monographs and textbooks of forensic medicine and foreign journals. Towards the end of his life he focused on the study of the cardiovascular system, anatomical terminology, and history of medicine. In addition to research, he paid much attention to the problems how to improve the quality of teaching. Rooks is a co-author of the first volume of the textbook "Human Anatomy", which was published in 1974. G. Rooks supervised five doctoral dissertations, and he also supervised a number of award-winning student papers. His pedagogical and scientific work was highly appreciated by both institutions of higher education.

G. Rooks died on 5 July 1975; he was buried in Pärnamäe Cemetery in Tallinn [10]. Next we will take a look at the textbook and manual of forensic medicine by Prof. G. Rooks. When compiling the 558-page work, the author used in addition to his personal experience the world's best textbooks of forensic medicine published in 1931-1933 and journal articles from the following five years. The structure of the table of contents follows the foreign experience of that time and the requirements that had taken shape when developing a three-semester course at the University of Tartu. An effort was made to offer everything that was necessary for a student to study forensic medicine. The added guidelines and legal norms made it possible to use the book both for practising physicians and lawyers, who had to deal with forensic medicine in their work. The foreword is followed by the list of abbreviations on sixteen pages. The presented material is divided into eight sections. The general section (44 pages) consists of four chapters in the following order: introduction, some legal comments, courts, forensic examination. The section on the death and the changes in the corpse (section 2,19 p) consists of four chapters: registration of deaths, death certificates, and corpse examination; death and its signs; early changes in the corpse; late changes in the corpse. The section on forensic thanatology (section 3, $182 \mathrm{p}$ ) consists of fourteen chapters: bodily injuries according to the weapon; bodily injuries according to the location; non-lethal bodily injuries and violence; killing, traumatic causes of death; suicide, traumatic methods of suicide and their differentiation from murder or accidents; dissection of the corpse, bones; hair and hairs; death because of suffocation; other violence-related injuries and kinds of death; sudden death because of internal (natural) causes; identification of a person; malingering and aggravation. The section of forensic sexology (section 4, 99 p) consists of seven chapters: potency, hermaphroditism; perverted and immoral acts; doubtful pregnancy and delivery; some problems of paternity; abortion; infanticide. The section of poisonings (section 5, 77 p) consists of seven chapters: about poisonings in general; caustic poisons; tissue poisons; blood poisons; prussic acid and its salts; poisons of the nervous system; food poisonings. The section on some problems of court psychiatry (section 6, $22 \mathrm{p}$ ) consists of two chapters: criminal responsibility and some other problems in court 
psychiatry. The section on medical deontology (section 7, $35 \mathrm{p}$ ) consists of five chapters: medical administration in Estonia; Chamber of Physicians; about the acquisition of doctor's licence and practising licence; doctor's rights and duties; doctor's responsibilities. The section on social care and social security (section 8, 31 p) consists of two chapters: social care and social security. At that time only the most recent foreign textbooks of forensic medicine included this last section with two chapters. The bibliographical list is presented in alphabetic order according to sections and chapters on nineteen pages and the alphabetical thematic index is provided on thirteen pages [11]. One should also mention here a compendium of lectures by G. Rooks MD "Forensic Medicine" that was published in 1937 by the publishing house "A. Aas Home University" [2].

Now it would be interesting to learn who were the authors of the first Latvian and Lithuanian textbooks of forensic medicine and when they were published because all the three Baltic countries gained their independence almost at the same time. The first Latvian textbook and manual of forensic medicine "Forensic Medicine and Medical Deontology ( 219 p) was published in Riga in 1931 by Ferdinand Neureiter (1893-1946), the founder of the Institute of Forensic Medicine at the University of Latvia and its first director. He came from Austria, moved to Riga in 1922 and had then mastered the Latvian language in a very short time [12]. The first ten opening pages of his book contain a foreword, list of used sources, and introduction. This is followed by the procedural part ( $13 \mathrm{p})$; forensic thanatology (16 p); medical, forensic, and legal causes of death (55 p); forensic biology (forensic somatology and psychiatry) (66 p); medical deontology (54 p) and the thematic index (5 p) [13]. In addition, F. Neureiter published "Guidelines for the forensic examination of corpses" [12].

In Kaunas in 1922 there appeared the first Lithuanian-language textbook "Forensic Medicine" by Vaclovas Viršila (1871-1929), the first lecturer of forensic medicine at Kaunas University [14]. It was a slim volume ( $88 \mathrm{p})$, but it included all the most important chapters in forensic medicine: the procedural section $(3 \mathrm{p})$, court sexo$\operatorname{logy}(17 \mathrm{p})$, traumatology (21 p), thanatology (6 p), asphyxia (10 p), toxicology (20 p). In addition, the textbook provided a brief overview of examining the evidence of biological background ( $4 \mathrm{p}$ ), court pathopsychology ( $5 \mathrm{p})$, followed by the table of contents (2 p) [15]. Next year saw the publication of the "Textbook for the Forensic Study of Corpses" by V. Viršila on 56 pages. Thereafter he started to publish a comprehensive manual of forensic medicine in the journal "Medicine". Unfortunately, he was able to complete only two chapters of the latter due to his premature death [14].

After a short overview of the first Estonian, Latvian, and Lithuanian textbooks of forensic medicine we could ask why was the first Estonian-language textbook and manual of forensic medicine published as late as in 1938 and not earlier. It could be explained by the following circumstances. The first director of the Institute of Forensic Medicine at the University of Tartu of the Estonian Republic, acting professor Aleksander Eberhardt Ucke MD (1864-1945) held this position for a very 
short time (slightly more than one year); at first he did not know any Estonian, and he did not learn it later either [16].

The next director of the institute Prof. S. Talvik intended to publish an Estonianlanguage textbook, but this plan did not materialize because of his many undertakings and premature death [17]. This plan may have been hampered to a certain extent by the fact that Afanassi Ignatovskii (1858-1935), Director of the Institute of Forensic Medicine at Jurjev (Tartu) University and professor of state medicine in the field of forensic medicine, had published in 1910 and 1912 an original twovolume textbook of forensic medicine in Russian [18], which had been one of the best of its kind in Russia and was therefore widely used by the first generations of students at the national university.

By way of conclusion one might say that Gerhard-Gottfried Rooks was a versatile and erudite professor. His 42-year scientific and pedagogical work made an important contribution to the development of medicine, the fruit of which was the first Estonian-language bulky and thorough textbook and manual of forensic medicine, written during the first half of his academic career.

\section{References}

1. Siilivask K., Palamets H. Tartu Ülikooli ajalugu III: 1918-1982. - Tallinn, 1982.

2. Estonian History Archives = EAA. Stack 2100. Series 2. Item 1031a. Personal file of G. Rooks.

3. EAA. - Stack 2100. Series 4. Item 78. Faculty Reports of the University of Tartu for 1924 .

4. EAA. - Stack 2100. Series I. Item 9739. Personal file of A. Ibrus.

5. Personal file of A. Raatma in the Archives of the University of Tartu.

6. Rooks G. Mõnda vastsündinud laste ja nende päramiste mõõtudest // Eesti Arst. 1925. - 5. - Lk. 133-136.

7. Personal file of G. Rooks in the Archives of the University of Tartu.

8. Kogerman-Lepp E. Gerhard Rooks 70-aastane // Nõukogude Eesti Tervishoid. 1971. - 5. - Lk. 380-381

9. Personal file of G. Rooks at the Personnel Department of the Tallinn Pedagogical Institute named after $\mathrm{E}$. Vilde.

10. Kogerman-Lepp E. 80 aastat Gerhard Rooksi sünnist // Nõukogude Eesti Tervishoid. - 1981. - 6. - Lk. 140-141.

11. Rooks $G$. Kohtuarstiteadus. - Tartu, 1938.

12. Bērzinšs U., Volksone V. Ferdinands Neireiters (1893-1946) // Acta MedicoHistorica Rigensia. - Riga, 1997. - Vol. III (XXII). - Pp. 233-236.

13. Neureiters F. Tiesmedicīna un ârstu deontologija. - Rīga, 1931.

14. Найнис И.-В. Основатель кафедры судебной медицины Каунасского 
медицинского института // Судебная экспертиза: Том V. - Ленинград, 1972. C. 14-15.

15. Viršila $V$. Teismo medicina. - Kaunas, 1922.

16. Kasmel J., Erits H. Prof. Aleksander Eberhardt Ucke - Eesti Vabariigi Tartu Ülikooli kohtuarstiteaduse instituudi esimene juhataja // Tartu Ülikooli ajaloo küsimusi: nr. 29. - Tartu, 1997. - Lk. 173-r77.

17. Rooks G. Prof. S. Talvik kohtuarstiteadlasena // Eesti Arst. - 1929. - 10. - Lk. 358-361.

18. Игнатовский A. С. Судебная медицина: Курс лекций: Том I-II. - Юрьев, 1910-1912.

\section{Jaan Kasmel, Tiiu Kasmel}

Centre for Physical Anthropology

University of Tartu

Lossi 36, Tartu 51003, Estonia

E-mail: jaanjkasmel@hot.ee 